\title{
TECHNICAL EDUCATION, TECHNICAL SKILLS DEVELOPMENT AND METHODS IN REMOTE LEARNING
}

\author{
Zlatica HULOVÁ*, Catholic University in Ruzomberok, Slovak republik \\ Mária KOŽUCHOVÁ, Comenius University in Bratislava, Slovak republik
}

Přijato: 2. 6. 2021 / Akceptováno: 13. 7. 2021

Typ článku: Výzkumná studie

DOI: $10.5507 /$ jtie.2021.008

\begin{abstract}
The technical education at all school levels is currently a very topical issue that is being widely discussed by professionals. It is necessary and imperative to improve the technical literacy of pupils to better prepare them for life in the new societal context. The change and development of technical thinking and skills also require fundamental changes in the pedagogical and psychological approaches in the training of the young generation. The aim of this paper is to present a part of a longitudinal research that studies the technical skills of pupils at the primary school level, the changes in the application of educational methods and strategies in the time of an unexpected pandemic, as well as the accompanied and extended remote learning in the selected Slovak schools. The research was carried out within the framework of the VEGA grant task No. 1/0383/19, "Analysis of the state of play in the technical education and the development of technical skills of pupils at the primary school level.
\end{abstract}

Key words: technical education, technical thinking, methods and strategies, remote learning.

\section{TECHNICKÉ VZDELÁVANIE, ROZVÍJANIE TECHNICKÝCH ZRUČNOSTÍ A METÓDY V ČASE DIŠTANČNEJ VÝUČBY}

\begin{abstract}
Abstrakt: Technické vzdelávanie na všetkých stupňoch škôl je v súčasnosti vel'mi aktuálnou témou, ktorá je v odborných kruhoch intenzívne pertraktovaná na všetkých úrovniach. Je potrebné a nutné, aby sa zlepšila technická gramotnost' žiakov tak, aby boli lepšie pripravení na život v novej spoločnosti. Zmena a rozvoj technického myslenia, rozvoj technických zručností, vyžadujú a zásadne menia aj pedagogicko-psychologické prístupy v samotnej príprave mladej generácie. Ciel’om predkladanej štúdie je prezentácia časti výskumnej longitudinálnej štúdie zameranej na skúmanie technických
\end{abstract}


zručností žiakov na primárnom stupni školy, zmeny v uplatňovaní edukačných metód v čase nečakanej pandemickej situácie, sprevádzanej a dlhšie trvajúcej dištančnej výučby na vybraných slovenských školách. Skúmanie sa realizovalo v rámci grantovej úlohy VEGA č. 1/0383/19, Analýza stavu v technickom vzdelávaní a rozvoj technických zručností žiakov na primárnom stupni školy.

Klúčové slová: technické vzdelávanie, technické myslenie, metódy a stratégie, dištančná výučba.

*Autor pro korespondenci: zlatica.hulova@ku.sk

\section{1 Úvod}

Technické revolúcie prebiehajúce jedna za druhou pomaly už po necelých dekádach (Hul’ová, 2019, s.17), zásadným spôsobom menia celú spoločnost'. Mení sa obchod, priemysel, či celé hospodárstvo s dynamickým a trvalým rozvojom systémového využivania nových technických a technologických výdobytkov tejto doby. Do značnej miery k týmto dynamickým zmenám týkajúcich sa práve využívania techniky a nových technológií, prispieva aj súčasná krízová situácia s nekontrolovaným šírením sa vírusu označovaným COVID-19, ktorý spôsobil celosvetovú pandémiu.

Pandémia a s ňou sprevádzané lockdowny po celom svete, sa dotkli všetkých oblastí spoločenského života. Pre oblast školstva, školskej politiky ale aj pre samotnú výchovu a vzdelávanie, pre prípravu mladej generácie do života plného nástrah, neistôt, neslobody pandemická situácia prináša množstvo nových, nečakaných problémov a situácií. Tie je potrebné operatívne riešit a hladat pritom najoptimálnejšie spôsoby nápravy, či riešenia nepripravených systémov k prekonávaniu prekážok bez strát a podla možností čo najmenších nedostatkov a dôsledkov. Nie vždy je to ale možné a nie vždy sa to zaobíde práve bez chýb, či chybných rozhodnutí.

Je samozrejmostou, že sa usilujeme nielen o celkový rozvoj žiakov, študentov a mladej generácie, ale potrebujeme, aby sa zlepšila technická gramotnost jednotlivcov tak, aby boli pripravení na život v meniacej sa spoločnosti. Zmena a rozvoj technickej gramotnosti závisí od rozvíjania technického, kritického a tvorivého myslenia, od rozvíjania technických zručností jednotlivcov, čo vyžaduje a zásadne mení aj pedagogicko-psychologické prístupy v samotnej príprave celej mladej generácie.

Autio (2016) sa vo svojej výskumnej štúdií venuje problematike, ako prejst’ od remeselnej výučby k technológiám. Podla autora by mal učitel’ viest̉ žiakov 
tak, aby sa učili konštruovat vedecké pojmy a poznali ich významy, aby im vedel sprostredkovávat videnie javov a objektov v bežnom prostredí, s ktorými sa dennodenne stretávajú a aby vedel technologické vzdelávanie využit ako prostriedok na výučbu a sprostredkovávanie vedeckých poznatkov aj v samotnom modernizovanom remeselnom vzdelávaní. Kožuchová - Dostál (2016) sa venujú zas problematike, ako prejst’ od tradičnej výučby k bádatel'sky orientovanej výučbe aj v technickom vzdelávaní žiakov mladšieho školského veku. Hul’ová $(2019,2020)$ uvádza, že už od najútlejšieho veku dietata je potrebné rozvíjat’ jemnú a hrubú motoriku a to aj prostredníctvom rozvíjania manuálnych zručnosti detí, prostredníctvom nových technologických postupov a nových metód výučby. Zapájaním zmyslov „oko - ruka“, sa rozvíja myslenie, rozvíjajú sa pracovno- technické zručnosti a samozrejme predstavivost' a tvorivost'. Neustálym pôsobením sa postupne prechádza k rozvíjaniu technického, kritického a tvorivého myslenia, $\mathrm{k}$ práci $\mathrm{s}$ technikou, $\mathrm{s}$ technológiami, multimédiami a k samotnému chápaniu aplikácie moderných technológií do života a sveta práce dietata. Práve to sa aktuálne ukazuje ako nevyhnutnost vzdelávacích potrieb. Deti, žiaci a študenti potrebujú v čase locdownov a dištančnej výučby dostávat informácie, úlohy a zadania pre tvorivé činnosti, pri ktorých je možné vyššie uvedené rozvíjat'.

Dillenbourg (2013), prezentuje ako učitel' môže uskutočňovat skriptovanie výučby pred ale aj počas výučby t. j. vediet robit úpravy pôvodných scenárov, pôvodných pripravených schém učenia a to podla dosahovaných výsledkov učiaceho sa (In Thi My Hang Vu, Pierre Tchounikine, 2021). Práve plánovanie, projektovanie a konkrétne učitelom zadávanie úloh by malo byṫ zamerané na rozvíjanie zručností aj počas dištančnej výučby, ktorú môže neustále upravovat', prispôsobovat a zdokonal'ovat'. U žiakov mladšieho školského veku je to dôležité nielen z hladiska pedagogického, ale aj psychologického a spoločenského. Žiaci v tomto veku potrebujú dostatok času na sebarealizáciu, na tvorbu vlastných nápadov a na získavanie sebavedomia a vnútornej motivácie k práci a činnostiam, ktoré sú im vlastné a vyplývajú z ich možností, schopností a jedinečnosti. Práve k tomu má možnost prispiet tvorivý, usmerňujúci učitel aj počas dištančnej výučby.

\section{Metodológia}

\section{Ciele}

Cielom štúdie je prezentácia jednej časti výskumnej longitudinálnej štúdie, ktorá je zameraná na skúmanie technických zručností žiakov tretieho a štvrtého roč- 
níka na primárnom stupni školy. Súčastou štúdie je aj čiastkový ciel’ zameraný na sledovanie zmien $\mathrm{v}$ uplatňovaní edukačných metód a stratégií v čase nečakanej pandemickej situácie, spôsobenej šírením vírusu COVID 19, ktorú sprevádzalo dlhšie trvajúcu dištančnú výučbu na slovenských školách.

\section{Metódy}

K skúmaniu problematiky rozvíjania technických zručností žiakov tretieho a štvrtého ročníka a na sledovanie edukačných metód a stratégií počas dištančnej výučby, bol skonštruovaný výskumný dizajn, ktorého súčastou bola kombinácia výskumných metód tak kvantitatívnych ako aj kvalitatívnych (rozhovory, dotazníky, štruktúrované pozorovanie, originálny záznamový hárok (Hulová, 2020) interview, pretesty, posttesty a balík programu SPSS verzia 2,0 na štatistické vyhodnocovanie získaných výskumných dát). Skúmanie prebiehalo striedavo a to aj $\mathrm{v}$ čase prezenčnej výučby (pretesty, testy, posttesty a pozorovanie počas zásahu) aj v čase dištančnej výučby (rozhovory, interview a dotazníky).

\section{Respondenti}

Skúmania sa zúčastnilo celkom 200 žiakov z vybraných škôl na Slovensku. Z toho bolo 100 žiakov tretieho ročníka a 100 žiakov štvrtého ročníka primárneho stupňa školy. Skupinu respondentov z tretieho ročníka tvorilo 54 dievčat 46 chlapcov a skupinu respondentov štvrtého ročníka tvorilo 50 dievčat a 50 chlapcov. Z toho bolo $80 \%$ žiakov majority a $20 \%$ žiakov minority. Počas skúmania pracovno-technických zručností žiakov participoval nielen výskumník, ale aj triedni učitelia vybraných tried zapojených do skúmania. Z 10 učitel’ov primárneho stupňa školy bolo 9 žien a 1 muž, ktorí sa zúčastnili aj interview.

\section{Výskumné nástroje}

Počas výskumu výskumník sledoval a hodnotil pracovno-technické zručnosti žiakov po všetkých troch stránkach rozvoja osobnosti žiaka a to po stránke kognitívnej (pretest), socioafektívnej(dotazník) a psychomotorickej (zásah- realizácia aktivít ). Z dôvodu rozsiahlej štúdie vyberáme a prezentujeme len zistenia týkajúce sa psychomotorickej stránky, ktorá prezentuje úroveň pracovno-technických zručností žiakov, aj ked' ju nie je možné skúmat izolovane. Výskumník a učitelia zapojení do skúmania zaznamenávali počas pozorovania hodnoty od 0 (najnižšie dosiahnutá úroveň rozvoja) do 10 (najvyššie dosiahnutá úroveň rozvoja), do záznamového hárku vlastnej konštrukcie (Hul’ová, 2020). Interview realizované 
s učitelmi pozostávalo zo 16 otázok, ktoré sa týkali názorov učitelov na technické vzdelávanie, na časovú dotáciu na primárnom stupni školy, na vybavenost̉ odborných učební, na výučbu technického vzdelávania a používanie metód a stratégií počas dištančnej výučby a iné.

\section{Zber údajov}

Zber výskumných dát prebiehal v troch fázach. Prvá fáza prebehla koncom júna 2020, kedy boli oslovené vybrané školy do výskumu a zároveň prebehlo interview. Po dohode s triednymi učitelmi prebehla $\mathrm{v}$ mesiacoch september až november 2020 druhá fáza zberu dát predchádzala jej dlhšia doba prerušenia prezenčnej výučby. Uskutočňovalo sa pozorovanie vo vybraných triedach tretieho a štvrtého ročníka až do d’alšieho prerušenia prezenčnej výučby $z$ dôvodu pandémie. Tretia fáza zberu dát prebiehala počas dištančnej výučby, kedy bol prostredníctvom dotazníkového dopytovania zistovaný spôsob, formy, metódy a stratégie výučby technického vzdelávania.

\section{Analýza údajov}

Dotazníkové dopytovanie a zistenia z interview boli spracované kvalitatívnou analýzou a zaznamenané do tabuliek a kvantitatívne dáta do grafov. Získané údaje z pozorovania boli z tabulkového editora MS Excel transformované do programu SPSS verzia 2.0 a uskutočnila sa deskripcia a interferencia. Použili sme parametrické a neparametrické testy. Z nich Mann-Whitneyho U-test, Wilcoxonov poradový test, Spearmanov korelačný koeficient, parametrický Párový T-test a iné.

\section{Výsledky skúmania}

Z prezentovaných výskumných výsledkov získaných z pozorovania činnosti žiakov na hodinách pracovného vyučovania považujeme za najvýznamnejšie zistenie, že žiaci tretieho a štvrtého ročníka základnej školy dosahujú nižšiu úroveň technických zručností oproti rokom 2015/2016/2017 (Hul'ová, 2020). Namerané hodnoty pri sledovaní 200 žiakov v jednotlivých činnostiach so stupnicou hodnotenia od 0-10, dosiahli najvyššiu hodnotu v priemere 5,49, kde 0 predstavuje (najnižšie dosiahnutú úroveň rozvoja) a 10 predstavuje (najvyššie dosiahnutú úroveň rozvoja). Tieto dosiahnuté hodnoty potvrdzujú potrebu prioritne venovat' pozornost̉ technickému vzdelávaniu už na primárnom stupni školy. 
Na meranie pracovno-technických zručností, ktoré boli merané cez všetky tri stránky rozvoja osobnosti žiaka (kognitívna, socioafektívna a psychomotorická), prezentujeme len meranie psychomotorickej stránky rozvoja žiakov, boli vybrané štyri druhy materiálov a to $\mathrm{v}$ zmysle tematických celkov zo vzdelávacej oblasti Človek a svet práce. $V$ činnostiach vyučovacích hodín na prácu boli použité papier, textil (nite, látka, bavlnky), kov (drôt, klinec), modelovací materiál (hlina) a drobný prírodný a technický materiál (koráliky, slamky, slama) a iné.

V nasledujúcich tabul'kách 1 a 2 sú prezentované zistenia, ktoré dokumentujú úroveň pracovno-technických zručností žiakov tretieho a štvrtého ročníka na primárnom stupni školy pri práci s papierom (trhanie, skladanie, strihanie, lepenie).

Tab. č. 1: Úroveň technických zručností žiakov 3. a 4.ročníka primárneho stupňa školy pri práci s papierom

\begin{tabular}{|c|c|c|c|c|c|c|c|}
\hline & ročník & $\begin{array}{l}\text { trhanie } \\
\text { po rovnej } \\
\text { línii }\end{array}$ & $\begin{array}{l}\text { trhanie väč- } \\
\text { ších kúskov }\end{array}$ & $\begin{array}{l}\text { trhanie } \\
\text { pravidelných } \\
\text { tvarov }\end{array}$ & $\begin{array}{c}\text { skladanie } \\
\text { po rovnej línii }\end{array}$ & $\begin{array}{l}\text { skladanie } \\
\text { pravidelných } \\
\text { tvarov }\end{array}$ & $\begin{array}{c}\text { skladanie } \\
\text { s presnostou }\end{array}$ \\
\hline \multirow[t]{2}{*}{ Mean } & 3. & 3.27 & 4.04 & 3.11 & 2.95 & 2.58 & 2.65 \\
\hline & 4. & 4.59 & 5.14 & 4.26 & 4.07 & 3.56 & 3.79 \\
\hline \multirow[t]{2}{*}{ Std. Deviation } & 3. & 1.763 & 2.132 & 1.369 & 1.336 & 1.208 & 1.359 \\
\hline & 4. & 1.311 & 1.712 & 1.440 & 1.742 & 1.380 & 1.423 \\
\hline T-test & & -6.008 & -4.024 & -5.767 & -5.101 & -5.343 & -5.793 \\
\hline Significance & & .000 & .000 & .000 & .000 & .000 & .000 \\
\hline
\end{tabular}

Tab. č. 2: Úroveň technických zručností žiakov 3. a 4.ročníka primárneho stupňa školy pri práci s papierom

\begin{tabular}{|c|c|c|c|c|c|c|c|}
\hline & ročník & držanie nožníc & $\begin{array}{l}\text { technika } \\
\text { strihania }\end{array}$ & $\begin{array}{c}\text { strihanie } \\
\text { po rovnej línií }\end{array}$ & $\begin{array}{l}\text { technika } \\
\text { lepenia }\end{array}$ & $\begin{array}{c}\text { správnost' } \\
\text { nanášania } \\
\text { lepidla }\end{array}$ & $\begin{array}{c}\text { rôznost' tech- } \\
\text { ník lepenia }\end{array}$ \\
\hline \multirow[t]{2}{*}{ Mean } & 3. & 3.01 & 2.47 & 2.37 & 2.82 & 2.70 & 2.24 \\
\hline & 4. & 4.11 & 3.86 & 4.04 & 4.36 & 4.62 & 4.28 \\
\hline \multirow[t]{2}{*}{ Std. Deviation } & 3. & 1.352 & 1.251 & 1.269 & 1.585 & 1.541 & 1.280 \\
\hline & 4. & 1.576 & 1.263 & 1.483 & 1.560 & 1.632 & 1.570 \\
\hline T-test & & -5.298 & -7.818 & -8.556 & -6.924 & -8.556 & -10.069 \\
\hline Significance & & .000 & .000 & .000 & .000 & .000 & .000 \\
\hline
\end{tabular}

Tabulky 3 a 4 zaznamenávajú zistenia, ktoré dokumentujú úroveň pracovno - technických zručností žiakov tretieho a štvrtého ročníka na primárnom stupni školy pri práci s kovom (drôt, klinec) a s drobným prírodným a technickým materiálom (koráliky, slamka, silon, slama). 
Tab. č. 3: Úroveň technických zručností žiakov 3. a 4.ročníka primárneho stupňa školy pri práci skovom

\begin{tabular}{|c|c|c|c|c|c|c|c|}
\hline & ročník & $\begin{array}{l}\text { držanie } \\
\text { nástroja }\end{array}$ & $\begin{array}{l}\text { technika } \\
\text { ohýbania } \\
\text { materiálu }\end{array}$ & $\begin{array}{l}\text { uchopenie } \\
\text { materiálu }\end{array}$ & držanie klieští & $\begin{array}{l}\text { technika } \\
\text { strihania } \\
\text { kov,drôt }\end{array}$ & $\begin{array}{c}\text { ohýbanie, } \\
\text { tvarovanie } \\
\text { materiálu }\end{array}$ \\
\hline \multirow[t]{2}{*}{ Mean } & 3. & 2.57 & 2.49 & 2.54 & 2.44 & 2.47 & 2.54 \\
\hline & 4. & 3.99 & 4.11 & 4.02 & 4.01 & 3.94 & 3.98 \\
\hline \multirow[t]{2}{*}{ Std. Deviation } & 3. & 1.233 & 1.580 & 1.283 & 1.486 & 1.684 & 1.500 \\
\hline & 4. & 1.617 & 1.490 & 1.563 & 1.617 & 1.523 & 1.263 \\
\hline T-test & & -6.982 & -7.461 & -7.319 & -7.148 & -6.473 & -7.342 \\
\hline Significance & & .000 & .000 & .000 & .000 & .000 & .000 \\
\hline
\end{tabular}

Tab. č. 4: Úroveň technických zručností žiakov 3. a 4.ročníka primárneho stupňa školy pri práci s drobným prírodným a technickým materiálom

\begin{tabular}{|c|c|c|c|c|c|c|c|}
\hline & ročník & $\begin{array}{l}\text { uchopenie } \\
\text { materiálu }\end{array}$ & $\begin{array}{l}\text { technika } \\
\text { navliekania } \\
\text { korálikov, } \\
\text { slamky }\end{array}$ & $\begin{array}{c}\text { pravidelnost' } \\
\text { navliekania } \\
\text { korálikov, } \\
\text { slamky }\end{array}$ & $\begin{array}{l}\text { rezanie slamy, } \\
\text { slamky }\end{array}$ & $\begin{array}{l}\text { lepenie } \\
\text { slamy }\end{array}$ & $\begin{array}{l}\text { ohýbanie } \\
\text { slamy }\end{array}$ \\
\hline \multirow[t]{2}{*}{ Mean } & 3. & 2.70 & 2.40 & 2.68 & 2.77 & 2.79 & 2.83 \\
\hline & 4. & 4.35 & 4.35 & 4.12 & 4.28 & 4.51 & 4.69 \\
\hline \multirow[t]{2}{*}{ Std. Deviation } & 3. & 1.087 & 1.119 & 1.213 & 1.286 & 1.233 & 1.484 \\
\hline & 4. & 1.783 & 1.914 & 1.701 & 1.700 & 2.013 & 2.073 \\
\hline T-test & & -7.901 & -8.794 & -6.891 & -7.084 & -7.287 & -7.296 \\
\hline Significance & & .000 & .000 & .000 & .000 & .000 & .000 \\
\hline
\end{tabular}

V tabulke 5 sú prezentované zistenia zo skúmania úrovne zručností žiakov pri práci s textilom (nite, látka, bavlnky) a pri práci s modelovacím materiálom (hlina)

Tab. č. 5: Úroveň technických zručností žiakov 3. a 4.ročníka primárneho stupňa školy pri práci s textilom a modelovacím materiálom

\begin{tabular}{|c|c|c|c|c|c|c|c|}
\hline & ročník & $\begin{array}{c}\text { navliekanie } \\
\text { do ihly }\end{array}$ & robenie uzlíka & $\begin{array}{l}\text { vyšívanie } \\
\text { základných } \\
\text { stehov }\end{array}$ & miesenie hliny & $\begin{array}{c}\text { válanie, } \\
\text { gúlanie } \\
\text { hliny }\end{array}$ & $\begin{array}{c}\text { formovanie, } \\
\text { tvarovanie } \\
\text { z hliny }\end{array}$ \\
\hline \multirow[t]{2}{*}{ Mean } & 3. & 2.85 & 2.53 & 2.13 & 3.09 & 2.59 & 2.49 \\
\hline & 4. & 4.04 & 4.15 & 4.73 & 4.75 & 4.64 & 4.54 \\
\hline \multirow[t]{2}{*}{ Std. Deviation } & 3. & 1.242 & 1.425 & 1.412 & 1.457 & 1.280 & 1.330 \\
\hline & 4. & 1.917 & 1.914 & 2.059 & 1.817 & 1.856 & 1.672 \\
\hline T-test & & -5.209 & -6.789 & -10.415 & -7.128 & -9.093 & -9.596 \\
\hline Significance & & .000 & .000 & .000 & .000 & .000 & .000 \\
\hline
\end{tabular}


Prostredníctvom originálneho dotazníka vlastnej konštrukcie sme okrem iného zistovali aké metódy a stratégie uplatňujú učitelia v čase pandémie a dištančného vzdelávania na realizáciu aktivít a činností žiakov v kontexte pracovného(technického) vzdelávania.

Výskumu sa zúčastnilo 200 učitelov. Výskumnú vzorku tvorili učitelia vybraných základných škôl na Slovensku, ktorí vyučujú predmet pracovné vyučovanie na primárnom stupni školy. Dotazník osobne distribuovali študenti externého štúdia predškolskej a elementárnej pedagogiky. V úvode dotazníka boli otázky zamerané na zistenie pohlavia, dosiahnutého vzdelania, dĺžky praxe a vekového zloženia respondentov. Ďalšie otázky sa týkali obsahu pracovného vyučovania, vybavenia odborných učební, či časovej dotácie predmetu. Prostredníctvom originálneho dotazníka sa získalo množstvo údajov. V predkladanej štúdií sú prezentované len zistenia z položky č.14, v ktorej sa zistovali vyučovacie metódy a stratégie uplatňované $\mathrm{v}$ dištančnej forme výučby $\mathrm{v}$ predmete pracovné vyučovanie. Zistenia sú zaznamenané v grafe 1 .

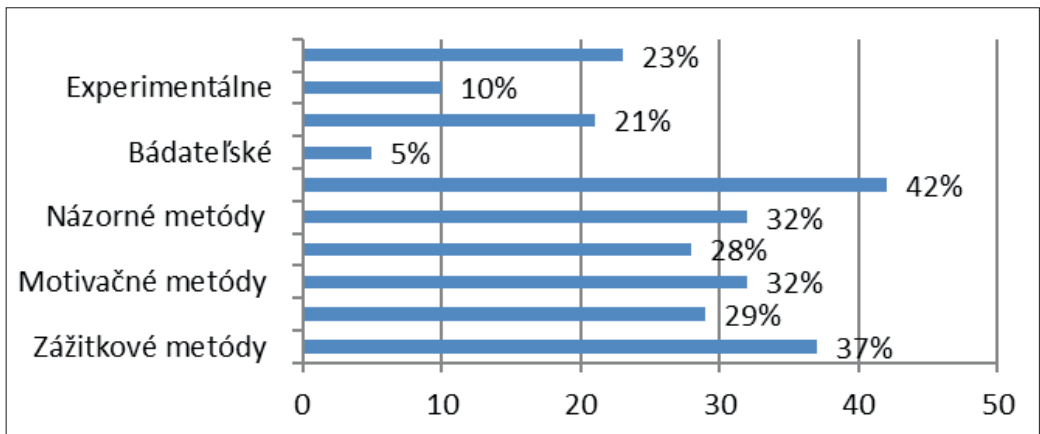

Obr. č. 1: Grafické znázornenie \% vyjadrenia učitel'ov, ktoré metódy sú najčastejšie uplatňované v pracovnom vyučovaní na primárnom stupni školy.

Zo skúmania metód a stratégií aplikovaných do výučby počas dištančného vzdelávania respondenti vo väčšom percentuálnom zastúpení uvádzali metódy klasické, bežne používané bez výrazných zmien (42\% - metódy praktických činností) a orientácie na metódy bádatelské, experimentálne, problémové, výskumné, projektové a pod. Práve tie, ktoré by boli vhodné počas zadávania pracovno- technických úloh a činností zameraných na rozvíjanie pracovno-technických zručností 
žiakov počas on-line, či of-line dištančnej výučby. Učitelia prezentovali metódy, ktoré bežne uplatňujú počas prezenčnej formy výučby.

V čase prvej vlny pandémie, v mesiacoch marec/ apríl 2020 odborníci ŠPÚ pri MŠVV a Š v SR vzdelávaciu oblast Človek a svet práce zaradili do skupiny tzv. komplementárnych vzdelávacích oblastí a odporúčali učitelom počas dištančnej výučby „obsah komplementárnych vzdelávacích oblastí využívat ako doplnkové aktivity nad rámec indikatívneho času vzdelávacej zátaže, prípadne sa môže integrovat do obsahu hlavných vzdelávacích oblastí (napríklad témy z oblasti Človek a svet práce sa môžu integrovat's témami z oblasti Človek a príroda, resp. s témami vo vzdelávacej oblasti Človek a spoločnost)“"(ŠPÚ, 2020). Prirodzene učitelia na základe takto formulovaného odporúčania, čo naznačujú výsledky skúmania tak nečinili, len s výnimkou malého percenta (10\%, 21\% a 5\%) učitelov, ktorí si potrebu rozvíjania pracovno-technických zručností u žiakov v mladšom školskom veku uvedomujú( zadávali úlohy na pozorovanie, aj projekty) a považujú to nielen za potrebu ale za nutnost aj v rámci komplementárnych obsahov vzdelávania. Práve to môže byt jeden z dôsledkov nameranej nižšej úrovne pracovno-technických zručností žiakov na primárnom stupni školy v porovnaní s predchádzajúcimi rokmi skúmania.

\section{Záver}

Longitudinálne skúmanie problematiky výučby technického vzdelávania na primárnom stupni školy odhaluje značné a opakujúce sa nedostatky spôsobované nesystémovým riešením technického vzdelávania, na ktoré už od roku 1990 apelujú odborníci zaoberajúci sa nielen teoreticky, ale hlavne výskumne danou problematikou. Je potrebné a nutné, aby sa zlepšila technická gramotnosť žiakov $\mathrm{k}$ príprave na život v novej spoločnosti. Rozvojom systémového využívania nových technológií, s dobre rozvinutými zručnostami je možné pripravit technicky a technologicky zdatnú generáciu. Je zrejmé, že bez kvalitnej prípravy orientovanej na získavanie základov pre nové budúce profesie, nebude možné dosiahnut požadovanú európsku kvalitu a konkurencieschopnosṫ našej krajiny.

Výskumy realizované aj za ostatné obdobie nasvedčujú nedostatočnú prípravu mladej generácie na nové profesie, na nedostatočne rozvíjané pracovno-technické zručnosti u žiakov v mladšom školskom veku, na nedostatočne nadobúdané nové kompetencie potrebné na prácu s novou technikou a s novými technológiami. Predstavitelia školskej politiky by mali venovat značnú pozornost’ a uskutočňovat’ 
podporu a neopomínat pri tvorbe kurikúl či legislatívy technické vzdelávanie. Rovnaký apel patrí aj na prípravu nových učitelov pripravujúcich sa v študijných odboroch predprimárneho a primárneho vzdelávania. Práve nová generácia mladých učitelov by mala byt pripravená na moderný spôsob výučby a vzdelávania mladej generácie už od najútlejšieho veku dietata.

Príspevok vznikol v rámci grantovej úlohy VEGA č. 1/0383/19 Analýza stavu v technickom vzdelávaní a rozvoj technických zručností žiakov na primárnom stupni školy, ktorého zodpovedná riešitelka je doc. PaedDr. Zlatica Hulová, PhD., (2019-2021).

\section{Literatúra}

Autio, O. (2016). Traditional craft or technology education: Development of students' technical abilities in Finnish comprehensive school. In International Journal of Research in Education and Science (IJRES), 2(1), 75- 84. Available from: https://www.researchgate. net/publication/305988274_Traditional_Craft_or_Technology_Education_Development_ of_Students\%27_Technical_Abilities_in_Finnish_Comprehensive_School. [accessed May 28 2021]

Dillenbourg, P. (2013). Design for classroom orchestration. Computers \& Education, 69, 485-492 In

Thi My Hang Vu, Pierre Tchounikine. 2021. Supporting teacher scripting with an ontological model of task-technique content knowledge. Computers \& Education 163 (2021) 104098. https://doi. org/10.1016/j.compedu.2020.104098 [accessed May 28 2021]

Hulová, Z. (2019). Technické vzdelávanie na primárnom stupni školy v historickom a medzinárodnom kontexte I. Ružomberok: PF KU v Ružomberku, Vydavatel'stvo VERBUM, 2019, - 1. vyd., 145 s. - ISBN 978-80-561-0686-0.

Hulová, Z. (2020). Technické vzdelávanie na primárnom stupni školy a vztah učitelov $k$ obsahu technického vzdelávania. Ružomberok: Katolícka univerzita v Ružomberku. VERBUM vydavatel'stvo KU, 2020. - 1. vyd., 149 s.- ISBN 978-80-561-0823-9.

Kožuchová, M. - Dostál, J.(2016). Badatelský př́stup v technickém vzdělávání: teorie a výzkum. 1. vyd. - Olomouc : Univerzita Palackého v Olomouci, 2016. - 211 s. - ISBN 978-80-244-49135.

Usmernenie k obsahu a organizácii vzdelávania žiakov základných škôl počas mimoriadneho prerušenia školského vyučovania v školách v školskom roku 2019-2020. Bratislava: Štátny pedagogický ústav pri MŠVVaŠ v SR, 2020. [cit.05-28-2021], dostupné na: https://www. statpedu.sk/sk/distancne-vzdelavanie/usmernenia-stanoviska-odporucania /usmernenie-kobsahu-organizacii-vzdelavania-ziakov-zakladnych-skol-pocas-mimoriadneho-preruseniaskolskeho-vyucovania-skolach-skolskom-roku-2019/2020/ 